Alderson, P. (2008) When does citizenship begin? Economics and early childhood. In A. Invernizzi and J. Williams (eds) Children and Citizenship, London: Sage, pp 108-119 isbn 9781412935381.

\title{
Introduction
}

What part as citizens have young children played, and do they currently play, in the economics of their family, community and state? Citizenship will be considered in this chapter for its economic implications, and for young children's contributions to the economics of their household and communities, as well as their entitlements to use public services and amenities. 'Public' is taken to mean beyond the household or family, in small or larger neighbourhoods, cities or counties, nation states, or global economic exchange. Tensions between 'citizenship' as membership of a city or nation state and the child's membership of the private family will be discussed. This historical review takes the example mainly of children in England, although with globalisation and international 'development', the patterns possibly apply to all countries, whatever stage of this history they presently occupy.

Increasingly, young children are seen as economic dependents, burdens and costs, and childhood is seen in capitalist terms as the opportunity to invest now for future productivity and profit, and also for the future redemption of debts and correction of present failings towards imagined better societies (Qvortrup, 2005). This chapter briefly traces the economic history of working children, the slow and reluctant growth of public support and protection for needy children, the welfare state, new international concepts of children's citizenship and rights, children's contributions to their health, education and welfare services, and the new English Children's Agenda. The final part reviews how criticisms of mainstream economics by alternative economic analyses open new ways to understand the economics and citizenship of early childhood.

\section{Working children}

Since human families and communities first began to form, young children have had to work. A short life span and subsistence living do not allow for the contemporary Western 10 or 20 years of economic dependence, as many of today's poorer communities demonstrate. Across the world, by their second year children tend to be keen to share in housework and other tasks they see their parents performing. Whether they are recognised as economically active or not, young children tend to help in and around the home and care for younger siblings, In poorer communities they may care for crops and animals, work in shops and market stalls, and they may produce goods for export that support their national economy. Traditionally girls in Leicester, England, started making hats when aged 3 years and were considered competent by 5 years. From babyhood, children share in managing their own health care and education, in washing, dressing, eating, exercising and learning. By 4 or 5 years, besides being fluent in at least one language, they have mapped out their life-long basic understanding of the world, self and other, space and time, science and morality, art and technology (Gardner, 1993). They show 
their skill not only in learning but also in organising their learning, such as through extended repetition, curiosity and exploring, through humour, inventing games and other imaginative play.

The transition in richer societies from viewing young children as productive workers to viewing them as economic dependents and burdens is less related to children's supposed incapacities to work than to adults' agendas. Excluding children from labour markets and from under-cutting adult workers' wages helps to protect adults' pay and conditions, which can benefit children when their parents are reasonably paid, but not in the many cases when their parents earn very little.

\section{Public support for needy children}

Historically, states have been reluctant to relate directly to children as citizens in their own right, and have avoided intervening within families either to provide for destitute children or to protect children from violent, abusive or neglectful parents. Still today, many citizens are unwilling to pay taxes to subsidise and, they fear, thereby to encourage inadequate parenting. Earlier deterrents to state economic or other intervention within families included beliefs that children were their fathers' property to dispose of as the father wished, and that interventions by the public state would undermine vital strong ties within the private family. This concern is currently seen in African states' reservations about public provision - funding and orphanages - for children affected by HIV/AIDS (van Blerk, 2005). Without state pensions or child benefits, families survive through strong triadic inter-generational loyalties and obligations. Younger adults, in supporting their parents repay their parents' earlier support for them, and in supporting their children help to ensure support for their own old age.

The reluctance to intervene within families is constantly illustrated by English legal history. Voluntary parish relief for the destitute began in 1536, soon to be replaced by compulsory local taxes to support the 'impotent poor' and their children, grandchildren and parents, in a Poor Law lasting almost 300 years, 1552-1834. Children could access services through their parents' entitlements, but illegitimate and abandoned children were more likely to die in a ditch or a gutter. Thomas Coram's Foundling Hospital for babies found in the streets or brought by their mothers opened in London in 1739. With its famous and wealthy patrons, the Hospital did much to challenge a public acceptance of infanticide similar to acceptance of abortion today, and to increase public support for children's right to life. Coram appealed to the public preference to support needy children by charity rather than by taxation in a tradition continued by charities such as Barnardo's, founded in 1866, and the National Society for the Prevention of Cruelty to Children, founded in 1884 long after the Royal Society for the Prevention of Cruelty to Animals was set up.

The 1834 Poor Law and its workhouses lasted until 1948, with the rise of the welfare state (when many of these large isolated institutions became life-long 'asylums' from birth of 'subnormal' people). To discourage applications to the 
workhouse, municipal budgets provided less for the inmates than the rations that destitute families might survive on at home, families were split apart, and vagrant paupers were turned away. The harsh regimes of the worst workhouses, 'baby-farms' and apprenticeships are described in such novels as Dickens's Oliver Twist (1838). State policies aimed to economise, to discipline the feckless poor, to deter dependence and to intervene only in cases of most extreme need. There was little state recognition of economic rights for any men, women or children, apart from property owners. Over centuries, land enclosures and the industrial revolution gradually ended the centuries old subsistence economy of most poor families with their small plots of land and cottage industries. Migration into cities particularly between 1850 to 1900 , the increase in women's employment outside the home, and the promotion of bottle feeding of babies endorsed by doctors who advised washing the bottle once a day or less often (Hardyment, 1984), all contributed to soaring perinatal and infant mortality rates.

\section{The welfare state}

The great Victorian local authorities laid the foundations for the welfare state, with their plumbing and transport infrastructures, schools and health and welfare services, public baths, museums and galleries. Concern about the poor health of potential recruits for the Boer War in 1899 accelerated eugenic policies to improve the nation's 'stock' through more school medical and school meals programmes (Cooter, 1992; Hendrick, 2003). Health and education policies took greater account of investing in children collectively as the nation's future. Social upheaval around the first world war 1914-1918 accentuated changes in attitudes towards poverty. There was less belief that individuals' class and income were ordained by God or wholly determined by the person's merit or failing. There was growing support for public obligations to promote education and opportunities and to prepare future adults to provide skilled labour, to support aging generations and to compete in global markets. Children were moving beyond patriarchy into a more visible status as recipients of public services with future public responsibilities. National Health Insurance was introduced for working men (and their families) in 1915, and new recognition was granted to 'widows and orphans' when national insurance was extended to them in 1926 although the related Parliamentary debate voiced a common concern about state provision.

For the tender care of the mother is replaced by the tender mercies of the state...natural affection ...by unnatural law. Better by far that many an infant should perish in its innocence and unconsciousness than to be victims of such a state of things (Cooke-Taylor quoted in Hardyment, 1984:114-5).

From 1948, the new state-funded National Health Service (NHS) provided medical and surgical treatment, optical, dental and pharmaceutical services to all children by right, instead of by charity, private wealth or rudimentary insurance. The 'psy' services to assess and advise on children's intellectual development and mental health also greatly expanded over the past century (Rose, 1990), along with NHS primary and hospital care, and medical 
research intended to benefit children. With new antibiotics and other medicines, inoculations and complex technologies, paediatric emphases altered from treating the deadly infections of tuberculosis, polio, diphtheria and smallpox, to supporting children who live with chronic conditions such as asthma, epilepsy, cerebral palsy, diabetes, cystic fibrosis, heart or kidney disease. Formerly, many of them would have died. From the 1970s, neonatology expanded, and today some babies born 17-18 weeks prematurely survive, physically and mentally intact in exceptional cases.

In wealthier countries, practitioners in state services - health, psychology, welfare, education, youth and early years - have promoted children's individual and collective rights to use their services, thereby increasing public funding and practical endorsement of these economic rights. Certainly, historical accounts of hungry lice-infested children in 1930s Britain, in ragged clothes and living in slums, show by comparison the great benefits of the welfare state since the 1940s. However, cost-effective questions, to be considered later, arise about how far the services directly benefit children, and political questions arise about how far the state with is current expansive policies should intrude into family and private life.

\section{New international concepts of children's citizenship and rights}

Established in 1945, the United Nations (UN) aims to prevent war by promoting peace, justice and health through international diplomacy and action. Over-represented in poorer states, children particularly stand to benefit from the UN's efforts at redistributive justice now and in the future. The UN Convention on the Rights of the Child (UNCRC 1989) recognises all children as citizens with economic rights and article 24 covers richer countries supporting poorer ones in meeting higher attainable standards of care for children. The aspiration is that:

Respecting the inherent worth and dignity and the inalienable rights of all members of the human family promotes social progress and better standards of life in larger freedoms, and lays foundations for justice and peace in the world (UNCRC, 1989 preamble).

There are clear economic aspects to implementing the UNCRC provision rights' necessities such as education, health care, an adequate standard of living, nutritious food and clean drinking water, and also the protection rights from abuse, neglect, exploitation, cruel or degrading treatment and discrimination. Participation rights also have costs, respecting children's rights to life and survival, to due process of law, to an identity and nationality so that states, which register their children from birth, begin acknowledgement of obligations towards them. For the key economic right to work (Liebel, 2004), the UNCRC sets conditions for protection from economic exploitation, from work that is hazardous or likely to interfere with the child's education, or to be harmful to the child's health or physical, mental, spiritual, moral or social development (article 32). States should set a minimum working age or ages, and should regulate and enforce hours and conditions of employment. There is a contradiction when states refuse to recognise child workers aged less 
than their set minimum age, and therefore do not offer protections to improve the working conditions of the youngest workers (Mizzen et al., 2001), who may be in most need of support. Just as feminists argue that much of their work is unpaid and unrecognised, so too is much children's work at home and school unrecognised and not even seen as 'work', but as 'learning or practising' supposedly mainly for the child's benefit. In narrowly defining work as 'paid employment' while vetoing slavery, the UNCRC overlooks how schooling involves very hard unpaid and enforced work and very long hours for many children.

The key concepts of children as citizens in article 12, with their rights to form and express views, to be consulted 'in all matters that affect' them, and for due account to be taken of their views, are sometimes criticised as potentially undermining children's protection and provision rights and best interests, if children resist adults' decisions about their welfare. However, no human rights are absolute, but are conditional upon national law and security, public order, health and morals, and avoidance of harm to third parties. Children's rights are further qualified by concerns to respect the child's best interests and parents' rights and responsibilities. The UNCRC only goes as far as children influencing matters that affect them, not being the main or sole decider. English law goes further, by recognising the child's right to decide (Gillick $v$. Wisbech \& Norfolk AHA 1985), but the Gillick/Fraser ruling is also limited. Children's decisions have to satisfy adults that they are competently made, informed, wise, and in the child's best interests. Article 12 tends to be classed as a civil and not an economic right. However, the next sections consider economic implications of article 12.

\section{Child citizens and public services}

During the past two decades, people using public services have been treated less as active citizens than as passive customers and consumers to whom services are 'delivered'. In contrast, effective (and cost-effective) education and healthcare depend on the child's active cooperation and partnership, when adults learning from children's 'views', as the following two examples illustrate.

During research about disabled children's views about their schools, I met 'Susan' (Alderson and Goodey, 1998:119-20). When 4 years old, she insisted on moving from her local reception class, where she felt 'smothered and mothered', to be a weekly boarder at a special school. She is blind though, like many children at that school, she is exceptionally far-sighted about life and values. Susan recalled how, 'Mum had to drag me screaming down the [school] drive because I didn't want to go home.' By 10 years of age, Susan was determined to be the first person in her family to go to university. She thought carefully about her secondary school choices and visited several schools to look round them. One was too rigid and unfriendly, she thought. Her local schools were not academic enough, but if she left her boarding school the LEA would force her to attend one of these. Yet she felt 'stifled' at her present school in a small class, and wanted a change. 'It's a really, really difficult decision,' she said. She decided to board at her present school and 
during the day to attend a nearby public school (on a very large split campus), sharing a liaison teacher with two other visually impaired students. 'It would be a struggle but I would get the hang of it,' she decided. Her father wrote a report explaining the decision for the LEA who approved Susan's choice. A year later she was very pleased with her decision, academically and socially. In some ways, Susan was the only person who could make a really informed decision that took account of her experiences, values and plans. She is academically successful, but during our research we found girls and boys with average abilities and with learning difficulties, who talked about their considerable insight into their own and their families' and friends' needs and interests, and how education services could help them most effectively or how it was unhelpful. Their understanding did not correlate with their age or assessed intelligence but with their experience.

In the second example, during an ethnographic study of four neonatal intensive care units (NICU), I observed 'John' and interviewed his mother and staff caring for him (Alderson, Hawthorne and Killen, 2005). (Altogether, we interviewed 40 senior staff and the parents of 80 babies.) The four NICUs differed markedly in the attention that was paid to learning from the babies. John was born 14 weeks early, and he was in the most 'baby-led' unit with great efforts made to keep the lighting and noise low. John looked relaxed and contented in a soft fabric 'nest' that, like the uterus, helped him to maintain a fetal curved position, limbs gathered together and hands close to his face, so that he could soothe himself by sucking his fingers or stroking his face. In some other NICU, babies' limbs hang over loose loops of rough toweling and they try to gather their splayed limbs together. The babies' subtle behaviours can be 'read' as their 'language' expressing their views and preferences (Als, 1999; Murray and Andrews, 2000). Babies constantly move through six states from deeply asleep, through quietly alert, to upset and crying and their observed competencies much depend on which state they are in (Brazelton and Nugent, 1995). Using Als's (1999) detailed observation programme, a staff member had written John's care plan, showing his 'strengths and sensitivities' (not deficits), and identifying 'goals and recommendations' for care. The plan, written 6 weeks after his birth when he still needed some mechanical support with breathing, presents John as a major agent in his own health care. His 'competencies' included:

- Initiating breathing movements much of the time;

- Smooth well organised movements to protect and calm himself;

- Making efforts to open his eyes in response to his mother's voice.

- Using strategies such as grasping and holding on, taking his hands to his face, putting his feet and hands together to calm himself.

Goals. From the observations today it appears that John's next steps are:

- Consistent efforts to breathe on his own;

- More time in restful sleep;

- Keeping firm muscle power with curled up posture;

- Being increasingly successful in calming himself.

Recommendations to help John 'achieve his goals' included, continuing to:

- work gently with John, respond to his signs of discomfort by pausing, soothing him with still hands and letting him settle before proceeding; 
- support his efforts to grasp, to clasp his hands or feet together, by Consider: offering your fingers to hold, by cupping his hands and feet.

- if it would be possible to position his bed where it is less light and busy;

- using bedding tucked around him and a stronger ridge around his feet to help him to find boundaries to push on and to help him contain some big tiring movements.

Three weeks later, John had made so much progress that the plans changed, for example, to 'continue to offer his dummy if it looks as if he might want to suck and let him choose if he wishes to take it into his mouth.' To encourage John to breastfeed, careful note was taken of the position in which he most liked to lie (on a pillow on his mother's knee, on his left or right side, supine or with shoulders raised), whether he began to feed too quickly and choked, and when he needed to take short breaks. The babies quickly became exhausted when trying to coordinate breathing, sucking and swallowing.

Approaches like the Als programme, which promote babies' own agency, are important in economically related ways. First, the adults can help the babies to sleep more deeply and so to gain strength to breathe, feed, grow, resist infections and become well enough to leave the NICU earlier, and thus to reduce costs (Goldson, 1999; Symington and Pinelli, 2004). Care for a longstay baby may cost over $£ 1$ million. Effective health care involves adults working in partnership with individual children and learning from their embodied knowledge, as we also found with young children who have diabetes, a condition that can have serious and expensive complications (Alderson, Sutcliffe and Curtis, 2006). Second, knowledge uniquely gained from closely observing and listening to individual children, and trying out different care techniques with them, can also be generalised to inform public services in order benefit many other babies and children. Within these childadult partnership approaches, respect for article 12 is integral to cost-effective protection and provision for children as citizens.

\section{The English Children's Agenda and child poverty}

This section reviews economic aspects of children's position as citizens in the English Government's Children's Agenda Every Child Matters (Treasury, 2003) and the 2004 Children Act (which covers England, and also Wales in non-devolved matters only). The Government's goals are primarily economic: to reduce child poverty, produce highly qualified, high earning future workers, and prevent costs of future crime and dependence (Treasury, 2003:5-6). The Treasury now dominates government policies for children. For example, the authors of the Childcare Bill (2005) are the Treasury, Department for Education and Skills (DfES) (meaning employable workers), Department for Work and Pensions and Department for Trade and Industry. In the Children's Agenda, every child is implicitly positioned as a threat to social cohesion and prosperity, at risk of not fulfilling personal potential, of becoming a criminal and of being abused. Victoria Climbé's name echoes through the documents, as a prototype of need, although from among 11 million children she was one of the 50-100 children per annum who die from abuse or neglect (Treasury, 
2003:15). Victoria was known to several children's services, and buck-passing might have contributed to her misfortunes. The potential for buck-passing will greatly increase when all children's services must be coordinated across all services with the aim of prevent abuse through very expensive, intrusive, time consuming, and controversial electronic databases of every child and family (see www.arch.org.uk for research and debate about the database and Agenda).

Historical themes continue in the Government's reluctance to fund poorer families directly. Child poverty is chiefly addressed by increasing parents' paid employment, and by specific early years interventions. A favourite quote in policy reports, to support expanding pre-school interventions, is from the US High/Scope Perry longitudinal study, which claimed that for every $\$ 1$ spent on part time pre-school interventions $\$ 7$ could be saved later. However, the three studies usually cited originated in the 1960s-70s with African-American children. They are 'not generalisable outside the US', partly because the cost calculations include estimations of 'highly controversial crime victim compensation figures' and very high imprisonment rates and costs among black youths (Penn et al., 2006:27). Penn and colleagues, who include economists, consider that reports of long-term cost-benefits after specific early years interventions are inevitably suggestive estimates. The reports say little about the quality and processes of the interventions, and ignore the young children's wellbeing and views. Penn et al. (2006:28-9) conclude that the findings are too tentative to support firm government policies, and that early childhood interventions alone cannot compensate for socio-economic inequalities in income, healthcare, schools, housing and local environments. However, instead of adopting redistributive policies, the Government continues to plan numerous targeted and assessed interventions or young children.

The Government claims to have consulted adults and children when planning the Children's Agenda, but children's influences are not clear, unless in the Agenda's unexceptionable five aims: to be healthy, stay safe, enjoy and achieve, make a positive contribution and achieve economic wellbeing. There is no mention of time with family and friends, fun and free leisure time, which are usually children's priorities. The Agenda aims to establish 3,500 children's centres based mainly in schools by 2010 for children aged 0-14 years. Extended schools will open from 8.00 a.m. to 6.00 p.m., 50 hours a week throughout the year, longer than European working hours for adults, because the 'childcare market' must meet all local needs for fully employable parents. Most of the related government funding will support new and refurbished buildings and bureaucratic structures to include: the DfES and Treasury Taskforce - to raise quality and ensure value for money; Transformation Fund $£ 125 \mathrm{~m}$; National Remodelling Team; Comprehensive Performance Assessment star rating; Annual Performance Assessment of Local Authorities and Outcomes Frame work; Regional Change Advisers; Local Authorities and Health Authorities; Voluntary, Statutory and Not-for Profit Services; Lead Members; Local Safeguarding Children Boards; the School Workforce in the Schools Directorate; Children's Workforce in Children, Young People and Family Directorate; a Pilot at the National College for School Leadership; 
Teams of 10 people on Multi-Agency Team Development Programmes; local Children's Trusts; Directors of Children's Services; Local Strategy Leaders; Joint Commissioning and Budgets; Integrated Front Line Delivery Multiagency Teams; Evaluators; New Relationships with Schools; Trainers; School Improvement Partners; OFSTED (the School Inspection Body); Joint Area Reviews; Consultants; Parents and Communities; children's centre staff (Treasury, 2001). It is unclear how flexible tailored care for each child, and respect for children's worth and agency are compatible with these expensive superstructures geared towards setting cost-effective testable targets. The Agenda will greatly expand the market in training and employing qualified 'experts' in children and the new Children's Workforce Development Council is one response to concerns that England has far too few skilled qualified childcare and education staff.

Child poverty in Britain has been rising since 1979. Although 750,000-800,000 children have been 'lifted out' of poverty since 1997, progress has slowed and it expected to be harder to assist the remaining groups of poor children living in households with under $60 \%$ of the median income adjusted for composition of households (JRF, 2006). In inner London, child poverty rates rose to 54\%, 700,000 children by $2004 ; 70,000$ of them were in temporary accommodation for homeless families (ECP and ALG, 2005). Current neo-liberal economics assumes that lightly regulated markets increase the national wealth and allow wealth to 'trickle down' throughout society. Despite being the wealthiest state in Europe, Britain is the least equal (ESRC, 2005) and has among the worst child poverty records, $21^{\text {st }}$ out of 24 (JRF, 2006). London had a $23 \%$ increase in its billionaire residents in the year up to April 2005. The top 1,000 richest people in Britain in 2005 owned $£ 249,615$ billion, whereas in 1997 they owned $£ 98.99$ billion. The share of the national wealth for the poorest $50 \%$ of British people was $10 \%$ in 1986 and fell to $5 \%$ by 2002 . Meanwhile, the cost of buying a home in London (usually the highest proportional cost of all for young families just starting their mortgage) doubled between 1996 and 2001 (Ingram, 2004). Many young families carry decades of debts and interest on student loans for higher education that was free for older people in Britain. The Children's Agenda expects working parents to pay for childcare until children are 14 years old, whereas in some Nordic countries, the strain on the family budget is far less when children look after themselves after school hours from around 8 years of age.

The 'prudent' government is rebuilding and refurbishing schools and hospitals at unprecedented rates, but avoids showing the true costs in its budgets. Instead it relies on private companies to build and rent out the premises and also run the public services within them. In use-now pay-later Public Private Partnership (PPP) contracts, today new buildings are being paid for, many times over, in the next 30, 40 or 60 years (Pollock, 2004). The PPP policy encourages firms to provide premises that are cheaper-to-build and expensive-to-run-and-repair as well as less ecological. The trademark atrium entrances, several stories high, absorb vast heating costs, and extensive repairs are among the extra burdens being transferred onto future generations. In addition to paying for their own services, they will have to continue PPP payments for our present services plus very high interest rates. 
Even if schools or hospitals have to close, PPP contracts ensure that the private companies will continue to be paid as if the buildings were fully used. For one school that closed, the local authority is paying over $£ 3,000$ per month for all the contracted school meals that are not being eaten. PPP policies imply that it will be easier for future generations to pay for our costs as well as their own. However, the reverse case is more likely when global warming and dwindling oil supplies multiply the cost of living.

Many researchers and voluntary organisations call for increased parental employment, tax credits and benefits for families. They deplore the high costs of childcare and housing, and the very low salaries that many parents earn (Thomas, 2001; Hirsch and Millar, 2004; Duncan et al., 2004; Millar and Gardiner, 2004; Bradshaw, 2005; ECP-ALG, 2005). Some debate the complications of defining and assessing poverty, social capital and social exclusion (Fine, 2001; Morrow, 2004; Mayhew et al., 2005; Pantazis et al., 2006). However, there is a broad tendency to support the government's concepts of economics in terms of monetary profit-loss, wealth and poverty, income and earning and spending power or potential, and the association of childhood poverty with the supposedly adverse outcomes of teenage pregnancy, 'workless' households, and 'lone' parenting.

Modern economies bring great material benefits for many children, but also serious problems. Economists, governments and the World Bank tend to assume that economic problems can be solved within the same economic paradigm and policies that produce poverty and inequality (Hedrick, 2003). The paradigm identifies wealth with money; aims to increase income and expenditure through trade and growing productivity; measures poverty relative to higher income households and states in ever escalating spirals of income and expenditure; and invests in intensive education, regulation and surveillance to produce future high-earning adults. However, clearer understanding childhood poverty's causes and solutions may be found in alternative economic paradigms, reviewed in the next section.

\section{Alternative economic paradigms}

Figure 1, The economies of the System and the Lifeworld

\begin{tabular}{|l|}
\hline Formal regulated economy - the System \\
\hline Private commercial sector, corporations, the market \\
\hline Government, public tax-funded sector, state services \\
\hline Unregulated economies - the Lifeworld \\
\hline Informal and underground economies \\
\hline Unpaid housework and subsistence work \\
\hline Family and communal reciprocity, voluntary work, self-help/support groups \\
\hline Free associations, amateur arts and sports, faith groups, protest groups \\
\hline Nature \\
\hline
\end{tabular}

Figure 1 is based on feminist economists' distinctions between the mainly male-dominated formal economy, and women's mainly unregulated, unrecognised and unrewarded work (Henderson, 1993; Mies, 1999). Children's even more invisible activities also largely belong to the lower rows. 
Feminists regard the commercial sector as absorbing and then discarding workers, unconcerned with the previous costs of childcare and education, the continuing costs of care at home, and the subsequent costs of caring for rejected, old, sick or disabled workers. Feminists argue that far from the top commercial layer generating all wealth and therefore supporting the whole society, commerce feeds off and depends on all the other layers.

Green economists emphasise how the formal economy exploits nature as an 'externality', a preferably free resource (land, air, water, minerals, forests) except for the labour required to process natural resources. Nature is also taken to be a free space for disposing of unwanted outputs, such as pollution and rubbish. Neo-liberal economics increasingly threatens the viability of the finite planet by plundering and polluting nature and driving for infinite growth, consumption and profit, (Kennett and Heinemann, 2006). Placing nature on the lowest rung of the economies, furthest from the commercial sector, has interesting suggestions for childhood as a partly natural state and a resource for renewing societies, as well as for how commerce tends to remove children from natural settings and into buildings and vehicles.

Green and other critical economists challenge the claims of mainstream economics to be a 'hard' mathematical science, supposedly dealing with timeless, value-free concepts. Greens argue that economics is socially constructed, heavily value laden and destructive, falsely identifying human psychology with competitive greed. Greens do not see money as the measure of all things, but as a volatile unreliable indicator and predictor, often of priceless natural and human resources. Although Gross Domestic Products (GDPs) measure economic growth and success in goods, they are also inflated by 'bads': the costs of crime, prisons, illness, disasters, accidents, waste and pollution. A US annual Index of Social Health measured the 'bads' of infant mortality, child abuse and poverty, teenage suicides, drug use, mental illness and high-school drop-out rates. During 1977-1994, as the GDP rose, and so too did the recorded incidence of these problems (Douthwaite, 1999), so that a healthy GDP does not equate with a healthy nation.

Alternative green economics proposals are based on holistic respect for the interconnectedness of all things, moral and aesthetic values, and a psychology of social solidarity. They favour simple, peaceful, harmonious ways of living rather than stressful competitive and violent ways; creating rather than consuming; promoting sustainable local trade instead of exploitative, wasteful global trade (Hamilton, 2003; Wall, 2005). Similarly, some childhood researchers suggest that instead of imposing Western values on children living in subsistence communities (Katz, 2004; Gupta, 2005; Penn, 2005) we have much to learn from them about more viable sustainable ways of sharing the planet among over 6 billion people. Feminist and green economic paradigms indicate that we need clearer distinctions between types of poverty, between destitution (to be prevented and relieved urgently) and the frugal thrift in which people in most times and places have lived and which, sooner or later argue the Greens, we will all be forced to re-adopt, so that social justice now demands more equal sharing of global resources (Mies, 1999; Mayer, 2000; Hillman and Fawcett, 2004). 
In figure 1, the feminist tiers have been adapted to fit Habermas's (1987) concepts of the System and the Lifeworld. The neo-liberal System (commerce, government and law, the power elite) colonises and absorbs the Lifeworld (personal and civic life). This process also involves turning social and political issues (such as childcare and education) into ones of technical expertise. Neo-liberalism further involves disorganised deregulated global capitalism, with the withdrawal of practical material support for citizens by the welfare state. However, the drawing back is accompanied by moving the state and economic power (the System) forward to invade and control both public and private life (the Lifeworld) through the kinds of Children's Agenda mechanisms listed earlier. People are treated less as active determining citizens, than as passive clients of state services and consumers guided by the mass media. Habermas considers that the encroaching System results in fewer shared meanings and understandings, social bonds and integration, with increased feelings of helplessness, alienation and demoralisation. Many areas of public life, schools and universities, charities and churches, and childhood itself are being drawn up into the top two layers to become more tightly regulated businesses. Extended children's centres, which confine children into one institution all week for 'wrap around care' under constant adult surveillance, isolating them into narrow age groups and away from all adults who are not paid carers or teachers, are likely to reduce children's status from contributing citizens into economic units whose performance gauges the school's cost-effectiveness. This could include the social exclusion of the youngest generations (Mayall and Zeiher, 2003) which the Children's Agenda is intended to overcome.

\section{Conclusion}

This chapter has reviewed young children's under-recognised citizenship in terms of their economic contributions to their families and communities. It suggests that concepts of 'delivering' health care and education services misunderstand the crucial contributions that children can make towards increasing the cost-effectiveness of public services to the benefit of themselves and potentially of many other children. Despite its unprecedented concern with private family life, the Government continues historical traditions in mainly encouraging self-reliance (parental paid employment) rather than direct material support for children. The multi-million pound Children's Agenda mainly funds buildings, committee, and other infrastructures, again rather than direct care of children. Alternative feminist and green economics point out gaps and problems in current mainstream economics, that have powerful implications for childhood, which so far have been little debated. There are risks that the System's over-concentration on monetary wealth and poverty and on children's future earning potential could turn children into hostages to the future, and paradoxically impoverish their present Lifeworld, restricting their citizenship, their enjoyments and relationships, freedoms and rights during their early years. 


\section{References}

Alderson, P. and Goodey, C. (1998) Enabling Education. London: Tufnell Press.

Alderson, P., Hawthorne, J. and Killen, M. (2005) 'The participation rights of premature babies', International Journal of Children's Rights, 13:31-50.

Alderson, P., Sutcliffe, K. and Curtis, K. (2006) 'Children as partners with adults in their medical care', Archives of Disease in Childhood, 91:300-305

Als, H. (1999) Reading the premature infant', in E. Goldson (ed.), Developmental Interventi'ons in the Neonatal Intensive Care Nursery. New York: Oxford University Press. Pp.18-85.

Bradshaw, J. (ed.), (2005) The Well-being of Children in the UK. Second edition. Plymouth: Save the Children/University of York.

Brazelton, T. B., Nugent, J. K. (1995). Neonatal Behavioral Assessment Scale, 3rd edition. Clinics in Developmental Medicine no. 137, London: MacKeith Press/CUP.

Children Act 2004 London: Stationery Office.

Cooter, R. (1992) In the Name of the Child: Health and Welfare 1880-1940. London: Routledge.

Douthwaite, R. (1999) 'The need to end economic growth', in M. Scott Cato and M. Kennett (eds.) Green Economics, pp. 27-35. Aberystwyth: Green Audit Books.

Duncan, S., R. Edwards, T. Reynolds and P. Alldred. (2004) Children \& Society, 18, 3:

ECP and ALG - End Child Poverty and Association of London Government. (2005) Not One of London's Children Lives in Poverty, 700,000 Do. London: ECP, ALG.

ESRC. (2005) www.esrcsocietytoday.ac.uk accessed 28/12/2005.

Fine, B. (2001) Social Capital versus Social Theory: Political Economy and Social Science at the Turn of the Millennium. London: Routledge.

Gardner, H. (1993) The Unschooled Mind: How children think and how schools should teach. London: Fontana.

Goldson, E. (ed.), (1999). Developmental Interventions in the Neonatal Intensive Care Nursery. New York: Oxford University Press.

Hardyment, C. (1984) Dream Babies - Child Care from Locke to Spock. Oxford: Oxford University Press

Hendrick, H. (2003) Child Welfare: Historical Dimensions, Contemporary Debate. Bristol: Policy Press.

Gupta, P. (2004) 'India', in H. Penn (ed.), Unequal Childhoods. London: Routledge Falmer. , pp. 119-141.

Habermas, J. (1987) The Theory of Communicative Action, Vol. 2: Lifeworld and System: A Critique of Functionalist Reason. Cambridge: Polity Press.

Hamilton, C. (2004) Growth Fetish. London: Pluto.

Henderson, H. (1993) Paradigms in Progress: Life Beyond Economics. London: Adamantine.

Hendrick, H. (2003) Child Welfare: Historical Dimensions, Contemporary Debate. Bristol: Policy Press.

Hillman, M. and T. Fawcett. (2004) How We Can Save the Planet. Harmondsworth: Penguin.

Hirsch, D. and J. Millar. (2004) Labour's Welfare Reform: Progress To Date. York: Joseph Rowntree Foundation. 
James, A. and James, A. (2001) 'Tightening the net: children community and control', British Journal of Sociology, 52,2:211-28.

Ingram, M. (2005) 'Labour policies make London a haven for the super-rich', World Socialist Web site, www.wsws.org/articles/2005/apr2005/lond-a23.shtml, accessed 20/12/2005.

JRF - Joseph Rowntree Foundation. (2006) What Will it Take to End Child Poverty? York: JRF.

Katz, C. (2004) Growing up Global: Economic Restructuring and Children's Everyday Lives. Minneapolis MN: University of Minnesota.

Katz, C. (2005) 'The Terrors of Hyper-vigilance', in J. Qvortrup (ed.) Studies in Modern Childhood, pp. 99-114, Basingstoke: Palgrave.

Kennett, M. and Heinemann, V. (eds). (2006) International Journal of Green Economics, volume 1/2.

Liebel, M. (2004) A Will of Their Own: Cross-cultural Perspectives on Working Children. London:Zed Books.

Mayall, B. and H. Zeiher (eds.) (2003) Childhood in Generational Perspective. London: Institute of Education.

Mayer, A. (2000) Contraction and Convergence: the Global Solution to Climate Change. Totnes: Green Books.

Mayhew, E., Uprichard, E., Beresford, B, Ridge T and Bradshaw, J. (2005) Children and Childhood in the United Kingdom. European Childhood Economics Survey, COST A19. pp 403-56.

Mies, M. with V. Bennholdt-Thomsen. (1999) The Subsistence Perspective. London: Zed Books.

Millar, J. and K. Gardiner. (2004) Low Pay, Household Resources and Poverty. York: Joseph Rowntree Foundation.

Mizen, P., Pole, C. and Bolton, A. (2001) Hidden Hands: International Perspectives on Children's Work and Labour. London: Routledge.

Morrow, V. (2004) 'Children's "social capital": implications of health and well-being', Health Education: 104, 4:211-225.

Murray, L. and Andrews, H. (2000). The Social Baby. Richmond: Children's Project Publishing.

O'Neill, J. (1998) The Market: Ethics, Knowledge and Politics London: Routledge.

Pantazis, C., D. Gordon, and R. Levitas (2006) Poverty and Social Exclusion in Britain: The Millennium Survey. Bristol: Policy.

Penn, H. (2005) Unequal Childhoods: Young Children's Lives in Poorer Countries. London: Routledge Falmer.

Penn,H., Burton, V., Lloyd, E., Mugford, M., Potter, S. and Sayeed, Z. (2006) Early Years: What is Known about the Long-term Economic Impact of Centre-based Early Childhood Interventions? London: EPPI-Centre, SSRU, Institute of Education.

Piachaud, D. (2001) 'Child Poverty, Opportunities and Quality of Life', The Political Quarterly, 72, 4:446-453.

Platt, L. (2005) Discovering Child Poverty: the Creation of a Policy Agenda from 1800 to the Present. Bristol: Policy.

Pollock, A. (2004) NHS.plc. London: Verso.

Qvortrup, J. (ed.), (2005) Studies in Modern Childhood. Basingstoke; Palgrave.

Rose, N. (1990) Governing the Soul. London: Routledge 
Symington, A., Pinelli, J, (2004). Developmental care for promoting development and preventing morbidity in preterm Infants. Cochrane Database Systematic Review, (3).

Thomas, N. (2001) Children, Family and the State: Decision-making and Child Participation. New York: St Martin's Press.

Treasury. (2003) Every Child Matters. London: Stationery Office.

Treasury, Department for Education and Skills, Department for Work and Pensions and Department for Trade and Industry. (2005) Childcare Bill. London: Stationery Office.

Qvortrup, J. (ed.), Studies in Modern Childhood. Basingstoke: Palgrave. pp. 99-114. van Blerk, L. (2005) Care giving during the AIDS pandemic in Southern Africa', Children, Families and States, conference at Institute of Education, London. United Nations (1989) Convention on the Rights of the Child, New York: UNICEF. Wall, D. (2005) Babylon and Beyond. London: Pluto Press. 